\title{
Effect of Acupressure versus Ginger on Gastrointestinal Side-Effects of Chemotherapy on Children with Leukemia
}

\author{
Rasha Mohamed Abohadida, Assistant Lecturer \\ Pediatric Nursing, Faculty of Nursing, Alexandria University \\ Magda Essawy, Professor \\ Pediatric Nursing, Faculty of Nursing, Alexandria University \\ Hoda M. Hassab, Professor \\ Pediatrics, Faculty of Medicine, Alexandria University \\ Wafaa Abd-Elkader, Assistant Professor \\ Pediatric Nursing, Faculty of Nursing, Alexandria University \\ Hoda M. Sherif, Lecturer \\ Pharmacognosy, Faculty of Pharmacy, Alexandria University
}

\begin{abstract}
Chemotherapy-induced nausea and vomiting are the most common gastrointestinal side-effects in children with leukemia. Frequent vomiting may lead to dehydration, electrolyte imbalance and depression. Non-traditional therapy such as acupressure and ginger has been recommended to be used for reducing the gastrointestinal disorders in children with leukemia. Objective: Assess the effect of acupressure versus ginger on gastrointestinal side-effects of chemotherapy for children with leukemia. Setting: The study was conducted at the Inpatient and Outpatient Hematology/Oncology Unit at Alexandria University Children's Hospital. Subjects: A convenience sampling of 90 children with acute lymphoblastic leukemia comprised the study subjects, their ages ranged from 7-15 years. The study subjects were randomly divided into three equal groups (control, acupressure and ginger groups). Tools: Three tools were used: Tool I: Assessment of Biosocial Data of Children, Tool II: Assessment of Nausea, Vomiting, Diarrhea and Dehydration, and Tool III: Assessment of Severity of Nausea and Vomiting by Visual Analogue Scale. Results: The present study revealed that the percentages of children who experienced nausea in ginger group were decreasing through the three days of the three studied sessions compared to the percentages of children in acupressure and control groups and significant differences were illustrated between the three studied groups $\left(1^{\text {st }}\right.$ session $X^{2}=91.05, P=0.00,2^{\text {nd }}$ session $X^{2}=83.07, P=0.00,3^{\text {rd }}$ session $\left.X^{2}=62.43, P=0.00\right)$. The same results were found regarding the children who experienced vomiting and significant differences were illustrated between the three studied groups $\left(1^{\text {st }}\right.$ session $X^{2}=92.67, P=0.00,2^{\text {nd }}$ session $X^{2}=81.76, P=0.00,3^{\text {rd }}$ session $\left.X^{2}=71.09, P=0.00\right)$. Concerning diarrhea none of the children in the three studied groups experienced diarrhea through the three days of $2^{\text {nd }}$ and $3^{\text {rd }}$ sessions and significant differences were clarified $\left(2^{\text {nd }}\right.$ session $X^{2}=6.07, P=0.05,3^{\text {rd }}$ session $\left.X^{2}=8.12, P=0.02\right)$. None of the children in ginger group experienced severe degree of nausea on the third day of the three studied sessions while, the acupressure group experienced severe degree of nausea through the third day of $1^{\text {st }}$ and $2^{\text {nd }}$ sessions in a percent of $66.7 \%$ and $25.0 \%$ respectively.. Conclusion: It was concluded from the current study that ginger lozenges has more effect than acupressure technique in alleviating the chemotherapy gastrointestinal side effects for children with leukemia. Recommendations: Ginger and acupressure for management of gastrointestinal side-effects can be considered in pediatric oncology unit protocols, and educational programs can be carried out for children with leukemia and their caregivers about this non-traditional therapy.
\end{abstract}

Keywords: Children with leukemia; Acupressure; Ginger; Gastrointestinal side-effects; chemotherapy.

\section{Introduction}

Leukemia is the most common malignancy in children under the age of 15 years. It is an abnormal proliferation of blood cells in the bone marrow and lymphatic system $^{(1)}$. Leukemia is classified into two types acute and chronic. Acute leukemia occurs in immature blood cells (blast cells) and chronic leukemia arises 
from mature blood cells ${ }^{(2,3)}$. Acute leukemia occurs commonly in children and is divided into Acute Lymphoblastic Leukemia (ALL) and Acute Myeloid Leukemia. Acute Lymphoblastic Leukemia represents nearly one-third of all childhood cancer. It occurs more frequently in boys than girls ${ }^{(4)}$.

According to American Cancer Society ${ }^{(5)}$, the global annual incidence of ALL is three cases per 100,000 children less than 15 years. In United States $(2019)^{(6)}$, the annual number of new cases of ALL was 5,930 (3,280 for males and 2,650 for females) and the mortality rate was 1,500 for both sex (850 for males and 650 for females). According to World Health Organization (2018), the total new cases of leukemia in Egypt were 4.314 (3.74\%) and the total mortality rate was $3.752(4.84 \%)$.

Several modalities are used for the management of leukemia which include; chemotherapy, radiotherapy, surgery, biological and immunotherapy. Chemotherapy is the most common treatment of leukemia that is used alone or combined with other therapy to destroy the leukemic cells. Children with leukemia who receive chemotherapy treatment frequently experienced side-effects due to damage of the healthy cells that grow and divide quickly such as cells of the mouth, digestive system and hair follicles. These side-effects include; stomatitis, nausea, vomiting, diarrhea and dehydration ${ }^{(7)}$. Nausea and vomiting has been estimated up to $70 \%$ of children undergoing chemotherapy, while diarrhea estimated $45 \%$ of them. These effects can be very debilitating and lead to dehydration, electrolyte imbalance, malnutrition and susceptibility to infections and metabolic imbalances, hyponatremia, hypokalemia and metabolic acidosis may occur weight loss which affects the children activities of daily living. Moreover, they can interfere with chemotherapy treatment by causing dosing delay or reduction which may have an impact on children survival ${ }^{(8)}$.

Recently complementary therapies are used for relieving the side-effects of chemotherapy, such as massage, aromatherapy, relaxation, meditation, art and music therapy, herbal therapy and acupressure $^{(9)}$.

Acupressure is one of complementary therapies and part of the Ancient Chinese traditional system of medicine that is based on the concept of Chi. The Chi energy that flows along multiple channels known as meridians. Along the meridians there are several controlling points for Chi energy flow which are called acupoints. If the energy flow in meridians is blocked, it can be restimulated properly by applying pressure on one or more of these acupoints. Acupressure can be applied by hand, elbow or with various devices. Practicing of acupressure requires some training and experience, but the technique is widely accessible, painless and inexpensive to any health care professionals ${ }^{(10)}$.

Ginger (The rhizome of Zingiber officinal) is widely used by Chinese medicine to treat several health problems. morning sickness, motion sickness, colic, stomach upset, irritable bowel syndrome, diarrhea, digestion problems, nausea and vomiting. It is also available in fresh or dried form, as ginger extract, ginger oil tinctures and capsules ${ }^{(11,12,13])}$.

Pediatric nurses play crucial role in implementing appropriate strategies to minimize Side-effects of chemotherapy as nausea, vomiting, diarrhea and dehydration. They are responsible for administering pharmacological agents, providing small frequent diet with less strong smells and increasing fluid intake through treatment sessions. In addition, the pediatric nurses should be up to date with effectiveness of non-pharmacological therapies that relieve nausea, vomiting, diarrhea and dehydration for children with leukemia ${ }^{(14)}$.

\section{Aim of the Study}

This study aimed to assess the effect of acupressure versus ginger on gastrointestinal side-effects of chemotherapy for children with leukemia. 


\section{Research Hypothesis}

Children with leukemia who receive acupressure exhibit less gastrointestinal side-effects of chemotherapy than those who receive ginger.

\section{Materials and Method}

\section{Materials}

Design: A quasi experimental research was used.

Setting: This study was conducted at the Inpatient and Outpatient Hematology/ Oncology Unit at Alexandria University Children's Hospital.

Subjects: A convenience sampling of 90 children with acute lymphoblastic leukemia comprised the study subjects.

Inclusion criteria: School age children and adolescence from 7-15 years old (according to Piaget's theory), children who receive intensive chemotherapy and free from other disorders as cardiac, renal, or other gastrointestinal disorders.

Epi-Info program was used to estimate the subject size; the minimal sample size was estimated to be 36 . The research sample was 90 leukemic children for better results and statistical analysis.Epi-Info program was based on the following: Population size $=40$ leukemic children, the expected frequency $=50 \%$, the acceptable error $=10 \%$ and the confidence coefficient $=95 \%$.

The study subjects were randomly divided into two equal experimental groups (acupressure and ginger group) and a control group which received the routine hospital care.

Tools: Three tools were used to collect the needed data:

\section{Tool I: Assessment of Biosocial Data of Children with Leukemia}

This tool was developed by the researcher. It included the demographic data of children; age, gender, level of educational and residence. The children's clinical data comprised the onset of disease, prescribed medication, prescribed chemotherapy. Children's body weight was assessed.

Tool II: Assessment of Nausea, Vomiting, Diarrhea and Dehydration of Children with Leukemia Interview Schedule

This tool was developed by the researcher after review of relevant and recent literatures ${ }^{(15,16)}$ to assess the nausea, vomiting, diarrhea and dehydration as gastrointestinal side-effects of chemotherapy. It included items related to nausea such as; experiencing of nausea after chemotherapy treatment, duration and frequency of nausea, aggravating and alleviating factors, associating symptoms and feeling of distress following nausea. It also included items related to vomiting such as; experiencing vomiting after chemotherapy treatment, estimating the amount of the vomiting, consistency and frequency of vomiting, associated with feeding of distress following vomiting and consuming antiemetic medication. Assessment of diarrhea included items related to experiencing of diarrhea, duration, amount, frequency, consistency and type of diarrhea. Responses for each item was recorded on four point Likert type scale for frequency $($ none $=0$, one to three times $=1$, four to six times $=2$, seven and more $=3$ ).

Assessment of the degree of dehydration was done in case of the complication of diarrhea. Every child of study subjects was assessed and classifies the degree of dehydration according to WHO (2014) ${ }^{(17)}$. Assessment of electrolyte value such as; sodium and potassium was obtained from patient chart as the routine hospital care.

\section{Tool III: Visual Analogue Scales (VAS)}

This tool was developed by Fairbank \& Davies (1980) ${ }^{(18)}$ and modified by Baxter $(2011)^{(19)}$. It is a self-reported device that is used to report subjective data concerning nausea and vomiting. It was adopted to measure the severity of nausea and vomiting. It consists of a $10 \mathrm{~cm}$ straight line which represents a continuum of intensity; it is a verbal descriptive scale $0=$ no nausea/ 
vomiting, 1 to less than $4=$ mild nausea/ vomiting, 4 to less than $7=$ moderate nausea/ vomiting, 7 to less than $10=$ severe nausea/ vomiting, $10=$ unbearable nausea/ vomiting.

\section{Method}

- Tools I and II were developed by the researcher after thorough review of literature and were tested for their content validity by five experts in the field of pediatric nursing. The validity for tool I was $97.5 \%$, tool II was $93.7 \%$ and tool III was $100 \%$ and tested for reliability by Cronbach's alpha test. Reliability coefficient for tool I was 0.92 and tool II was 0.78 , which means the tools were reliable.

- The researcher received a special training in the field of acupressure at the Faculty of Physical education, Alexandria University.

- A pilot study was carried out on nine children who were suffering from acute lymphoblastic leukemia to test the feasibility of the tools and accordingly the necessary modifications were done. Those children were excluded from the study subjects.

\section{- Procedure:}

- Preparation of Ginger lozenges:

- Ginger lozenges was prepared by the pharmacist as followed; $1 \mathrm{~kg}$ dried powdered ginger was purchased from the local stores, extracted with $70 \%$ alcohol for two days, filtered and the filtrate evaporated under reduced pressure to give brownish residue. Gelatin Base for preparing chewable lozenge was prepared according to this formulation, (this quantity was sufficient to prepare 420 lozenges):
Glycerin $155 \mathrm{~mL}$, Gelatin $43.4 \mathrm{gm}$, Water $10 \mathrm{~mL}$, Methylparaben $0.44 \mathrm{gm}$ in a beaker. Water, glycerin and methylparaben, were combined, stirred and heated on a boiling water bath for five minutes over a three-minute period, very slowly.

- The gelatin added while stirring until it is thoroughly dispersed and free of lumps and then heated for additional 45 minutes, the mixture was removed from heat, cooled and refrigerated until used. After preparing the extract, the gelatin base was melted using a water bath. The extract was added to the melted gelatin base and thoroughly mixed until evenly dispersed. $20 \mathrm{~g}$ of commercial gelatin strawberry flavored powder was added. Continuously mixed and then poured into the pediatric chewable lozenge molds and allowed to cool then refrigerated.

- The chewable lozenges were immersed in a mixture of starch and crystalline sugar after extraction from the molds to coat and protect them from sticking to each other and provide them with good taste attractive for the children. 3000 s were prepared as mentioned above containing the extract of $1 \mathrm{~kg}$ powdered ginger. In other words, each 3 lozenges contained the extract of 1 gm powdered ginger. Patients were given 3 
lozenges daily equivalent to $1 \mathrm{gm}$ powdered ginger $^{(20)}$. Calculation of ginger dose was based on the children's body weight, i.e. one gram of ginger was calculated for the weight ranging between $20-40 \mathrm{~kg}$ and two grams for the weight that was more than $40 \mathrm{~kg}^{(21)}$. Children in ginger group were instructed to take the prepared ginger capsule with water 30 minutes before meal for three times daily for three days. They were free to choose whether to swallow or chew the lozenges. This was done for three consequent sessions of chemotherapy.

- Assessment of nausea, vomiting, diarrhea and dehydration were done and recorded daily for three days of each session by the researcher by using tools two and three.

\section{- For Acupressure group:}

- Acupressure included stimulating key points along body's meridians called acupoints to stimulate the flow of energy and correct Chi energy imbalances. The researcher calculated the cun measurement based on each child's fingers by using measuring tape in order to determine the location of pericardium six acupoint. Pericardium six acupoint was located on the palmar aspect of the forearm, 2 cun above the transverse crease of the wrist, between palmaris longus and flexor carpi radialis tendons ${ }^{(22)}$.
- The measurement of 2 cun was calculated by measured the width of the three fingers of each child when they were held together in dorsal aspect at the level of proximal interphalangeal joint of the middle finger and transform into centimeter. The researcher placed the tap measure below the child's wrist for the premeasured width then placed the thumb to fell the two large tendons. The researcher pressed on PC6 acupoint by using thumb for 10 minutes in each arm in a circular movement, in clockwise direction.
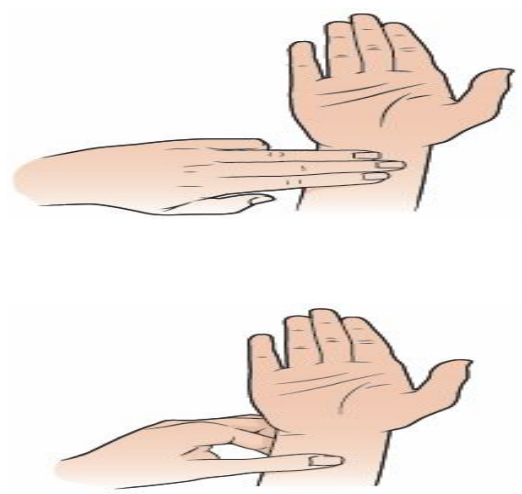

Figure (1)

- Acupressure was carried out three times daily 20 minutes before meal for three consequent sessions of chemotherapy by using tools two and three.

- Assessment of nausea, vomiting, diarrhea and dehydration was done and recorded daily for three days of each session by the researcher using tools two and three.

- Follow up: The researcher assessed the degree of nausea, vomiting, diarrhea and 
dehydration for children in three groups in the fourth day of $3^{\text {rd }}$ session of chemotherapy using tool two and three.

- The data was collected over a period of 15 months from June 2017 to September 2018. Data were collected first from control group then the study groups to prevent data contamination. Assessment of children gastrointestinal side effects were done before administration of chemotherapy.

\section{Ethical considerations:}

The study received ethical approval from the Ethics Committee of the Faculty of Nursing, written witness consent of children's parents was obtained after explaining the aim of the study and their rights to withdraw from the study at any time. Parent was ascertained about confidentiality of their children's data. Privacy and anonymity were considered. An official letter was obtained from Faculty of Nursing and sent to the director of the inpatient and outpatient oncology department of Alexandria University Children's Hospital at Smouha. The permission was taken to facilitate the research implementation after explaining the aim of the study.

\section{Statistical Analysis}

After data were collected, they were coded and transferred into specially designed formats so as to be suitable for computer feeding. The statistical package for social sciences (SPSS version 21) was utilized for both data presentation and statistical analysis of the results. Cronbach's alpha reliability test was used to measure the reliability of tools I and II, descriptive measures included; count, percentage, arithmetic mean and standard deviation, comparisons within and between groups were carried out using Chi-Square test $\left(\chi^{2}\right)$ and the level of significance selected for the present study was P less than 0.05 .

\section{Results}

Table (1) illustrates characteristics and clinical data of studied children. It was found that more than half of children's ages in control, acupressure and ginger groups ranged from seven to nine years (56.7\%,63.3\% and $56.7 \%$ respectively). The majority of children in this study were male in the three groups (80\%, 83.3\%,73.3\% respectively) and most of them had primary education $(83.3 \%, \quad 86.7 \%$ and $93.3 \%$ respectively).

It portrayed that more than two thirds of studied children in the three groups (control, acupressure and ginger) were living in urban area $(73.3 \%, \quad 70.0 \%$ and $66.7 \%$ respectively).Concerning the clinical data of children, it was illustrated that more than half of children in acupressure group were suffering from leukemia since two months (56.7\%) compared to $46.7 \%$ and $40.0 \%$ in control and ginger groups respectively. All children in control, acupressure and ginger groups were used Zofran ${ }^{\circledR}$ as antiemetic medication $(100 \%)$. The table showed also that the mean and standard deviation of children's body weight in control group were $30.07 \pm 9.794$ compared to $26.30 \pm 8.502$ and $25.50 \pm 5.296$ in acupressure and ginger groups respectively.

Table (2) shows the chemotherapy gastrointestinal side-effects of children experienced nausea. It illustrated that the percentages of children who experienced nausea were decreasing through the three days of $1^{\text {st }}$ session in ginger group $(60.0 \%$, $23.3 \%$ and $13.3 \%$ respectively) compared to the percentages of children in acupressure group $(93.3 \%, 80.0 \%$ and $13.3 \%$ respectively).While, all children in control group $(100 \%)$ experienced nausea through the three days of $1^{\text {st }}$ session. Significant difference was found between the three studied groups $\left(X^{2}=91.05, P=0.00\right)$.

Concerning the $2^{\text {nd }}$ session, the same results were clarified. Where, the percentages of children who experienced nausea were decreasing through the three 
days of $2^{\text {nd }}$ session in ginger group $(70.0 \%$, $36.7 \%$ and $3.3 \%$ respectively) compared to the percentages of children in acupressure group $(93.3 \%, \quad 60.0 \%$ and $10.0 \%$ respectively).While, all children in control group $(100 \%)$ experienced nausea through the three days of $2^{\text {nd }}$ session. Significant difference was showed between the three studied groups $\left(\mathrm{X}^{2}=83.07, \mathrm{P}=0.00\right)$

Regarding the $3^{\text {rd }}$ session, it was found that the percentages of children who experienced nausea were decreasing through the first two days of $3^{\text {rd }}$ session in ginger group $(66.7 \%$ and $26.7 \%$ respectively) compared to the percentages of children in acupressure group $(73.3 \%$ and $80.0 \%$ respectively).While, all children in control group $(100 \%)$ experienced nausea through the first two days of $2^{\text {nd }}$ session. Moreover, $20.0 \%$ of children in ginger group experienced nausea on the third day of $3^{\text {rd }}$ session compared to children in acupressure $(6.7 \%)$ and control (80.0\%) groups. Statistical significant difference was found between the three studied groups $\left(X^{2}=62.43\right.$, $\mathrm{P}=0.00)$.

Table (3) presents chemotherapy gastrointestinal side-effects of children experienced vomiting. It was found that $30.0 \%$ of children in ginger group experienced vomiting on the first day of $1^{\text {st }}$ session compared to $73.3 \%$ of children in acupressure group and all children in control group (100\%). In addition, it was clarified that none of children in ginger group experienced vomiting on the second and third day of $1^{\text {st }}$ session compared to children in acupressure (10\% and $3.3 \%$ respectively) and control (100\%) groups. Significant difference was found between the three studied groups $\left(X^{2}=92.67, P=0.00\right)$. It was showed from the same table that the percentages of children who experienced vomiting were decreasing through the three days of $2^{\text {nd }}$ session in ginger group (33.3\%, $13.3 \%$ and $3.3 \%$ respectively) compared to the percentages of children in acupressure group $(60.0 \%, 10.0 \%, 6.7 \%$ respectively). While, all children in control group (100\%) experienced vomiting through the three days of $2^{\text {nd }}$ session. Significant difference was illustrated between the three studied groups $\left(\mathrm{X}^{2}=81.76, \mathrm{P}=0.00\right)$.

Concerning the $3^{\text {rd }}$ session, it was observed that the percentages of children who experienced vomiting in ginger group were decreasing through the first and second day of $3^{\text {rd }}$ session $(36.7 \%$ and $0.0 \%$ respectively) compared to the percentages of children in acupressure (46.7\% and $20.0 \%$ respectively) and control (100\%) groups. It was noticed that the percentage of children in ginger group who experienced vomiting $6.7 \%$ was more than the percentage of children in acupressure group $(0.00 \%)$ on the third day only of third session. While, it was $80.0 \%$ for children in control group. Statistical significant difference was found between the three studied groups $\left(\mathrm{X}^{2}=71.09\right.$, $\mathrm{P}=0.00$ ).

Table (4) shows the chemotherapy gastrointestinal side effects of children experienced diarrhea in the three groups. It was clarified that small percentages of children in control, acupressure and ginger groups experienced diarrhea only on the first day of $1^{\text {st }}$ session $(16.7 \%, 10.0 \%$ and $3.3 \%$ respectively). While, none of children in the same groups experienced diarrhea on the second and third day of $1^{\text {st }}$ session.

Regarding $2^{\text {nd }}$ session, it was found only that small percent of children in control group experienced diarrhea on the first day of $2^{\text {nd }}$ session $(10 \%)$ compared to none of children in ginger and acupressure groups. Concerning the second and third day of $2^{\text {nd }}$ session, it was observed that none of children in the three groups experienced diarrhea. Significant difference was found between the three studied groups $\left(\mathrm{X}^{2}=6.07\right.$, $\mathrm{P}=0.05)$. Concerning the first day of $3^{\text {rd }}$ session, it was illustrated that $13.3 \%$ only of children in control group experienced diarrhea compared to none of children in acupressure and ginger groups .In addition, none of children in control, acupressure and ginger groups experienced diarrhea on the second and third day of $3^{\text {rd }}$ session. 
Significant difference was showed between the three studied groups $\left(\mathrm{X}^{2}=8.12, \mathrm{P}=0.02\right)$.

Table (5) presents the chemotherapy gastrointestinal side effects of children experienced dehydration in the three studied groups. The only item that has been noticed by small percent of children in acupressure and ginger groups in experienced dehydration on the first day of $1^{\text {st }}$ session ( $10.0 \%$ and $3.3 \%$ respectively) compared to $16.7 \%$ of children in control group. Concerning the second and third day of $1^{\text {st }}$ session, it was showed that none of children in the three studied groups experienced dehydration. Moreover, none of children in control, acupressure and ginger groups experienced dehydration through the three days of $2^{\text {nd }}$ session.

Regarding the first day of $3^{\text {rd }}$ session, it was found that small percent of children in control group experienced dehydration $(6.7 \%)$ compared to none of children in the acupressure and ginger groups. Plus, none of children in the three studied groups experienced dehydration in the second and third day of $3^{\text {rd }}$ session.

Figure (2) and (3) portray the severity of nausea and vomiting in the $1^{\text {st }}$ session in acupressure and ginger groups. Although the significant difference was not illustrated $\left(\mathrm{X}^{2}=2.35, \mathrm{P}=0.31\right)$, it was revealed that $25.0 \%$ of children were experiencing severe degree of nausea on the third day of $1^{\text {st }}$ session of acupressure group compared to none of children in ginger group (figure 2). In addition all children had mild degree of vomiting on the third day of 1 st session of acupressure group compared to none of children in ginger group and significant difference was not found $\left(\mathrm{X}^{2}=1.14, \mathrm{P}=0.29\right)$ (figure 3).

Figure (4) and (5) show the severity of nausea and vomiting in the $2^{\text {nd }}$ session in acupressure and ginger groups. Although the significant difference was not found $\left(\mathrm{X}^{2}=0.60, \mathrm{P}=0.74\right)$, it was noticed that more than two thirds of children experienced severe degree of nausea on the third day of $2^{\text {nd }}$ session of acupressure group $(66.7 \%)$ compared to none of children in ginger group (figure 4). In addition, it was clarified that all children experienced mild degree of vomiting on the first day of $2^{\text {nd }}$ session in acupressure group (100\%) compared to $90 \%$ of children in ginger group and the significant difference was found $\left(\mathrm{X}^{2}=10.10\right.$, $\mathrm{P}=0.01$ ) (figure 5).

Figure (6) and (7) portray the severity of nausea and vomiting in the $3^{\text {rd }}$ session in acupressure and ginger groups. Although the significant difference was not found $\left(\mathrm{X}^{2}=0.76, \mathrm{P}=0.69\right)$, it was observed that the percentages of children who experienced severe degree of nausea through the three days were decreasing in ginger group (50\%.0.0\% and $0.0 \%$ respectively) compared to the percentages of children in acupressure group $(63.3 \%, 16.7 \%, 0.0 \%$ respectively) (figure 6). Moreover, it was showed that all children had mild degree of vomiting on the second day in acupressure group (100\%) compared to none of children in ginger group. while, none of children had mild degree of vomiting on the third day in acupressure group compared to all children in ginger group $(100 \%)$ and significant difference was not illustrated $\left(\mathrm{X}^{2}=0.00\right.$, $\mathrm{P}=1.00$ ) (figure 7).

\section{Discussion}

Leukemia is the cancer in the bone marrow and blood $^{(6)}$. There are several strategies to treat leukemia; chemotherapy is considered the standard therapy for children with acute leukemia in the aim of controlling the disease ${ }^{(12,23)}$. In spite of the efficiency of chemotherapy, it could damage the normal as well as leukemic cells that lead to a variety of side-effects ${ }^{(24)}$. Nausea and vomiting are the most distressing sideeffects of chemotherapy ${ }^{(25)}$. Non-traditional interventions such as relaxation technique, self-hypnosis, biofeedback, thought aversion technique, guided imagery, music therapy, herbal therapy (e.g. ginger) and acupressure are effective in reducing the frequency of nausea and vomiting ${ }^{(26)}$. 
The findings of the present study revealed that the percentages of children who experienced nausea in ginger group were decreasing through the three days of the three studied sessions compared to the percentages of children in acupressure and control groups. The significant differences were illustrated between the three studied groups (table 2). The same result was found for children who experienced vomiting and significant differences were illustrated between the three studied groups (table 3 ).

The superiority effect of ginger therapy in the present study could be explained in the light of certain issues; ginger has antiemetic properties and anti-serotonin effects on the gastrointestinal and central nervous system. Anti-serotonin activity prevents serotonin from binding to 5-hydroxytryptamine (5-HT3) serotonin receptors at the ends of the vagus nerve's afferent branches, which send signals directly to vomiting center in the medulla oblongata that induce emetic response ${ }^{(12)}$. It was reported that ginger acts peripherally within the gastrointestinal system by increasing the gastric tone and motility due to anti-cholinergic and anti-serotonergic actions $^{(26)}$. Moreover, Mustian et al. $(2011)^{(27)}$ mentioned that ginger binds with 5-HT3 receptors to enhance antiemetic effects and increase detoxification enzymes to counteract oxidative damage to tissues. Jellin et al. $(2002)^{(28)}$ reported that ginger increases gastrointestinal motility and transports via the 6-gingerol constituent that act on 5-HT3 receptors in the ileum to illicit an anti-emetic effect.

The findings of Sontakke et al. (2003) ${ }^{(29)}$ were congruent with the current study as they mentioned that powdered ginger root is an effective therapy in reducing nausea and vomiting induced by low dose cyclophosphamide . Saberi et al. (2013) ${ }^{(30)}$ recommended in their study that ginger has more effect than acupressure to relieve nausea and vomiting which controls serotonin receptors at the level of the digestive system. Alparslan et al. $(2012)^{(31)}$ suggested also that ginger has a strong effect on nausea and vomiting where it acts on the gastrointestinal system by increasing gastric motility, absorption and decreasing stimuli to the chemoreceptor zone in the medulla that sends stimuli to the emetic center of the brain.

The findings of present study clarified that none of children in ginger group experienced severe degree of nausea in the third day of the three studied sessions while, the experienced severe degree of nausea was shown in acupressure group for two-thirds of children in the third day of $1^{\text {st }}$ session and one quarter of children in the third day of $2^{\text {nd }}$ session and significant difference was illustrated (figures 4, 6). These findings supported that the components of ginger were absorbed rapidly within 15 minutes after oral consumption ${ }^{(32)}$.

Some authors studied the effect of ginger capsules intake on treating morning sickness and reported that ginger capsules has an effect on reducing the intensity of nausea and vomiting, because of its content of gingerols and shogaols that promote the rapid improvement ${ }^{(33)}$. The findings of and Arslan \& Ozdemir ${ }^{(34)}$ were congruent with the present study where they stated that ginger supplementation significantly reduce the severity of acute chemotherapy-induced nausea through a combination of antiinflammatory and anti-spasmodic activities of ginger. On contrary, the study results of Arfeen et al. (1995) ${ }^{(35)}$ were disagreement with the findings of the current study where they mentioned that ginger has not significant effect on nausea and vomiting.

Children undergoing chemotherapy are at risk for diarrhea due to the effect of chemotherapeutic agents on the gastrointestinal system which causing damage to the villi and reducing the surface area of absorption ${ }^{(36)}$. It is illustrated from the present study that small percentages only of children experienced diarrhea in the first day of $1^{\text {st }}$ session in control, acupressure and ginger groups. Plus, none of children experienced diarrhea through the three days 
of $2^{\text {nd }}$ and $3^{\text {rd }}$ sessions in acupressure and ginger groups and the significant differences were clarified (table 4). These results could be related to the fact that frequency of chemotherapy induced diarrhea depends on the type of chemotherapeutic agents and administration schedule. Moreover, administration of lower doses of chemotherapy over a long period of time ( 2 to 3 years) in the management of acute lymphoblastic leukemia (ALL) might be a cause of the low percent of children who are experiencing diarrhea ${ }^{(6)}$.

The effect of ginger therapy on reducing diarrhea is still in advance than acupressure technique in the current study where, the percent of children who are experiencing diarrhea in ginger group was smaller than others (table 4). The results of study that have been done by Khalili et al. (2014) ${ }^{(37)}$ were congruent with the present study findings as ginger has anti-inflammatory, antioxidant effect which enhances digestion of gastrointestinal system and has strong antibacterial and antifungal properties that inhibit multiplication of bacteria in the colon. The reports that have been stated by World Health Organization (1999) ${ }^{(38)}$, were paralleled with these findings where it emphasized the use of ginger in the treatment of nausea, vomiting and diarrhea.

In the current study, dehydration was observed in small percent of children experienced dehydration on the first day of $1^{\text {st }}$ session in control, acupressure and ginger groups, while none of children in acupressure and ginger groups experienced dehydration through the three days of $2^{\text {nd }}$ and $3^{\text {rd }}$ sessions (table 5). These findings could be related to the small percent of children who are experiencing diarrhea through the sessions of chemotherapy as well as the early intervention for all children undergoing chemotherapy by receiving intravenous fluid following chemotherapy to replace the fluid loss. In addition, administration of oral ginger before starting chemotherapy might be a cause of reduction of dehydration through sessions (table 5).
The result of present study showed that acupressure technique has a reasonable effect on reducing nausea and vomiting for children undergoing chemotherapy but its effect was still following the effect of ginger therapy (tables 2, 3). The improvement that has been shown by acupressure technique on children's nausea and vomiting could be related to its activation on the gastrointestinal acupoints cross the meridians which correct the chi flows imbalance and blood circulation that controlled the organs dysfunction ${ }^{(39,40)}$. It is also stated that there are different nerve fibers in the body that carry signals to the brain at different speeds. The neurological signals that trigger nausea pass to the brain through slower small diameter nerve fibers cause nausea and vomiting. Touch and pressure signals that arrived by the application of acupressure at specific points will activate sensory receptors and sending faster pressure sensation signals to the brain and interrupting the signals that trigger the vomiting center ${ }^{(41)}$.

Some authors reported that acupressure technique stimulates target acupoints on the body and promotes blood circulation which eliminate chemotherapy induced nausea and vomiting ${ }^{(42,43)}$. Others stated that acupressure relieves muscle tension and promote blood circulation which has a significant role in the reduction of nausea and vomiting ${ }^{(44)}$. In his study supported the application of acupressure at Pericardium six (PC6) and he found a significant reduction in frequency, duration and severity of nausea and vomiting.

It was revealed by results of the present study that acupressure technique was following the ginger therapy on reduction of diarrhea and dehydration (tables 4,5 ). These findings could be related to the fact that acupressure technique improves spontaneous bowel movements by stimulating certain gastrointestinal acupoints. May be because it promotes gastrointestinal motility as well as it regulates the gastric acid secretion ${ }^{(45)}$. 
Malagoli et al. (2015) cited that children who live in urban areas are more liable to pollution than other. Where, they are in a great chance of exposure to atmospheric benzene and other pollutants from motor vehicular traffic. Other sources releasing potentially carcinogenic chemicals waste and spread of infectious agents through interpersonal contact $^{(46)}$. The results of present study confirmed this issue, where nearly three quarters of studied children in control, acupressure and ginger groups were living in urban areas (table 1).

Many authors reported that males are more liable to affect with childhood leukemia than females. They have a higher overall incidence of leukemia compared to females with a ratio of $2: 1^{(44,47,48)}$. This was congruent with the findings of the current study where the majority of children were males in the three studied groups (table 1) more than half of children's ages in the three groups were ranging from 7 to 9 years Effect of point 6 acupressure on chemotherapy associated nausea and vomiting among adolescents with cancer

It was revealed from the present study that more than half of children's ages in the three studied groups ranged from 7 to 9 years (table 1). These findings could be related to the fact that the peak incidence of childhood leukemia ranged from 2-8 years $^{(49)}$. It is also mentioned that leukemia is the most commonly diagnosed childhood malignancies in children under 14 years ${ }^{(50)}$.

In a brief, all over the study period almost $64 \%$ of children aged 13-15 suffered from nausea versus almost $55 \%$ of both categories aged 7-9 and 10-12. Boys suffered more than girls from nausea 58.5 versus $51.6 \%$.again, $40 \%$ of $13-15$ suffered from vomiting, $25 \%(10-12)$ and $37 \%$ (7$9)$. The youngest suffered from dehydration in a $4 \%$ especially boys $(8 \%$ of boys suffered from dehydration)

Acupressure alleviates the nausea best in the group aged 13-15 (55\% didn't suffer from nausea whilst the other two groups were almost $49 \%$. On the contrary ginger helped more the other two groups to be relieved from nausea more as $69 \%$ of the group 7-12 didn't suffer from nausea, versus half of the population ages 13-15.

The $\%$ in the control group was $11 \%$ (7$12)$ and $14 \%$ (13-15) both acupressure and ginger affected girls (44 \%, 27\% incidence of nausea respectively) more than boys $(52 \%, 33 \%)$ compared to $(90 \%$ from girls, $87 \%$ from boys).

As for vomiting incidences, acupressure again helped the oldest group (13-15) scored $90 \%$ free from vomiting compared to $78 \%$ in the (10-12 age group and $73 \%$ in (7-9) age group.

The effect of Ginger was almost the same as it alleviated the incidence of vomiting in both older group in a percentage almost $96 \%$ compared to $81 \%$ in (7-9) group.

It is worth mentioning that the control group $62 \%$ of (7-9) children reported vomiting, $74 \%$ (10-12) and $60 \%$ (13-15).

The acupressure effect on vomiting incidence didn't differ in both males and males, whilst ginger helped the males more (10\% reported vomiting versus $21.3 \%$ of the females).

\section{Conclusion}

It can be concluded from the present study that ginger powdered capsule as a nontraditionalal therapy has a great effect in alleviating the chemotherapy gastrointestinal side effects followed by acupressure technique for children with leukemia.

\section{Recommendations}

- Educational programs and training courses about non-traditional medicine such as ginger and acupressure in order to minimize chemotherapy gastrointestinal sideeffects can be carried out periodically for pediatric oncology nurses. 
- Ginger and acupressure as nontraditional medicine for management of gastrointestinal side-effects can be considered in pediatric oncology unit policy and protocols.

- Video tapes/booklets about the benefits of ginger and application of acupressure in the management of gastrointestinal side-effects can be available for health personals in pediatric oncology unit.

- Educational programs can be carried out for children with leukemia and their caregivers about non-traditional medicine such as; ginger and acupressure to minimize chemotherapy gastrointestinal sideeffects. 
Table (1): Socio-Demographic and Clinical Data for Children with Leukemia

\begin{tabular}{|c|c|c|c|c|c|c|}
\hline \multirow[t]{2}{*}{ Characteristics } & \multicolumn{2}{|c|}{$\begin{array}{l}\text { Control } \\
(\text { no=30) }\end{array}$} & \multicolumn{2}{|c|}{$\begin{array}{c}\text { Acupressure } \\
(\text { no=30) }\end{array}$} & \multicolumn{2}{|c|}{$\begin{array}{c}\text { Ginger } \\
(\text { no=30) }\end{array}$} \\
\hline & No & $\%$ & No & $\%$ & No & $\%$ \\
\hline $\begin{array}{l}\text { Age in years } \\
7-\end{array}$ & 17 & 56.7 & 19 & 63.3 & 17 & 56.7 \\
\hline $10-$ & 8 & 26.7 & 7 & 23.3 & 11 & 36.7 \\
\hline $13-15$ years & 5 & 16.7 & 4 & 13.3 & 2 & 6.7 \\
\hline $\begin{array}{l}\text { Min-Max } \\
\text { Mean } \pm \text { SD }\end{array}$ & \multicolumn{2}{|c|}{$\begin{array}{c}7-14 \\
9.60 \pm 2.283 \\
\end{array}$} & \multicolumn{2}{|c|}{$\begin{array}{c}7-14 \\
9.30 \pm 2.246 \\
\end{array}$} & \multicolumn{2}{|c|}{$\begin{array}{c}7-13 \\
9.27 \pm 1.929 \\
\end{array}$} \\
\hline $\begin{array}{l}\text { Sex } \\
\text { Male } \\
\text { Female }\end{array}$ & $\begin{array}{c}24 \\
6\end{array}$ & $\begin{array}{l}80.0 \\
20.0\end{array}$ & $\begin{array}{c}25 \\
5\end{array}$ & $\begin{array}{l}83.3 \\
16.7\end{array}$ & $\begin{array}{c}22 \\
8\end{array}$ & $\begin{array}{l}73.3 \\
26.7\end{array}$ \\
\hline $\begin{array}{l}\text { Level of education } \\
\text { Primary school } \\
\text { Preparatory school }\end{array}$ & $\begin{array}{c}25 \\
5\end{array}$ & $\begin{array}{l}83.3 \\
16.7\end{array}$ & $\begin{array}{c}26 \\
4\end{array}$ & $\begin{array}{l}86.7 \\
13.3\end{array}$ & $\begin{array}{c}28 \\
2\end{array}$ & $\begin{array}{c}93.3 \\
6.7\end{array}$ \\
\hline $\begin{array}{l}\text { Residence } \\
\text { Rural } \\
\text { Urban }\end{array}$ & $\begin{array}{c}8 \\
22\end{array}$ & $\begin{array}{l}26.7 \\
73.3\end{array}$ & $\begin{array}{c}9 \\
21\end{array}$ & $\begin{array}{l}30.0 \\
70.0\end{array}$ & $\begin{array}{l}10 \\
20\end{array}$ & $\begin{array}{l}33.3 \\
66.7\end{array}$ \\
\hline $\begin{array}{l}\text { Income } \\
\text { Enough } \\
\text { Not Enough }\end{array}$ & $\begin{array}{c}24 \\
6\end{array}$ & $\begin{array}{l}80.0 \\
20.0\end{array}$ & $\begin{array}{c}21 \\
9\end{array}$ & $\begin{array}{l}70.0 \\
30.0\end{array}$ & $\begin{array}{c}22 \\
8\end{array}$ & $\begin{array}{l}73.3 \\
26.7\end{array}$ \\
\hline $\begin{array}{l}\text { Onset of disease in months } \\
1.5-\end{array}$ & 6 & 20.0 & 0 & 0 & 6 & 20.0 \\
\hline $2-$ & 14 & 46.7 & 17 & 56.7 & 12 & 40.0 \\
\hline $3-$ & 8 & 26.7 & 9 & 30.0 & 12 & 40.0 \\
\hline 4 months \& more & 2 & 6.7 & 4 & 13.3 & 0 & 0.0 \\
\hline $\begin{array}{l}\text { Antiemetic Medication } \\
\text { Zofran }\end{array}$ & 30 & 100.0 & 30 & 100.0 & 30 & 100.0 \\
\hline Other Antiemetic Drugs & 0 & 0.0 & 0 & 0.0 & 0 & 0.0 \\
\hline $\begin{array}{l}\text { Body Weight } \\
\text { Less than } 40 \mathrm{~kg}\end{array}$ & 24 & 80.0 & 27 & 90.0 & 30 & 100.0 \\
\hline $40 \mathrm{~kg} \&$ more & 6 & 20.0 & 3 & 10.0 & 0 & 0 \\
\hline Mean \pm SD & \multicolumn{2}{|c|}{$30.07 \pm 9.794$} & \multicolumn{2}{|c|}{$26.30 \pm 8.502$} & \multicolumn{2}{|c|}{$25.50 \pm 5.296$} \\
\hline
\end{tabular}


Acupressure,Ginger, Chemotherapy GIT Side-Effects

Table (2): Chemotherapy Gastrointestinal Side -Effects of Children Experienced Nausea in the Three Groups

\begin{tabular}{|c|c|c|c|c|c|c|c|c|c|c|c|c|c|c|c|c|c|c|c|c|c|}
\hline \multirow{3}{*}{$\begin{array}{l}\text { Experience of } \\
\text { nausea }\end{array}$} & \multicolumn{6}{|c|}{$\begin{array}{c}1^{\text {st }} \text { session } \\
(\mathrm{n}=30)\end{array}$} & \multirow{3}{*}{$\begin{array}{l}\mathrm{Sig} \\
\mathrm{X}^{2}\end{array}$} & \multicolumn{6}{|c|}{$\begin{array}{c}2^{\text {nd }} \text { session } \\
(\mathrm{n}=30)\end{array}$} & \multirow{3}{*}{$\begin{array}{l}\text { Sig } \\
\mathrm{X}^{2}\end{array}$} & \multicolumn{6}{|c|}{$\begin{array}{c}3^{\text {rd }} \text { session } \\
(\mathrm{n}=30)\end{array}$} & \multirow{3}{*}{$\begin{array}{l}\text { Sig } \\
X^{2}\end{array}$} \\
\hline & \multicolumn{2}{|c|}{ Day 1} & \multicolumn{2}{|c|}{ Day 2} & \multicolumn{2}{|c|}{ Day 3} & & \multicolumn{2}{|c|}{ Day 1} & \multicolumn{2}{|c|}{ day 2} & \multicolumn{2}{|c|}{ Day 3} & & \multicolumn{2}{|c|}{ Day 1} & \multicolumn{2}{|c|}{ Day 2} & \multicolumn{2}{|c|}{ Day 3} & \\
\hline & $\mathrm{N}$ & $\%$ & $\mathrm{~N}$ & $\%$ & $\mathrm{~N}$ & $\%$ & & $\mathrm{~N}$ & $\%$ & $\mathrm{~N}$ & $\%$ & $\mathrm{~N}$ & $\%$ & & $\mathrm{~N}$ & $\%$ & $\mathrm{~N}$ & $\%$ & $\mathrm{~N}$ & $\%$ & \\
\hline $\begin{array}{l}\text { Control } \\
\text { group } \\
\text { Yes } \\
\text { No }\end{array}$ & $\begin{array}{c}30 \\
0\end{array}$ & $\begin{array}{l}100.0 \\
0.0\end{array}$ & $\begin{array}{c}30 \\
0\end{array}$ & $\begin{array}{l}100.0 \\
0.0\end{array}$ & $\begin{array}{c}30 \\
0\end{array}$ & $\begin{array}{l}100.0 \\
0.0\end{array}$ & $\begin{array}{c}0.00 \\
P=1.00\end{array}$ & $\begin{array}{c}30 \\
0\end{array}$ & \begin{tabular}{|l|}
100.0 \\
0.0
\end{tabular} & $\begin{array}{c}30 \\
0\end{array}$ & $\begin{array}{c}100.0 \\
0.0\end{array}$ & $\begin{array}{c}30 \\
0\end{array}$ & $\begin{array}{l}100.0 \\
0.0\end{array}$ & $\begin{array}{c}0.00 \\
P=1.00\end{array}$ & $\begin{array}{c}30 \\
0\end{array}$ & $\begin{array}{c}100.0 \\
0.0\end{array}$ & $\begin{array}{c}30 \\
0\end{array}$ & $\begin{array}{l}100.0 \\
0.0\end{array}$ & $\begin{array}{c}24 \\
6\end{array}$ & $\begin{array}{l}80.0 \\
20.0\end{array}$ & $\begin{array}{l}12.86 \\
P=0.00\end{array}$ \\
\hline $\begin{array}{l}\text { Acupressure } \\
\text { group } \\
\text { Yes } \\
\mathrm{N}_{0}\end{array}$ & $\begin{array}{l}28 \\
2\end{array}$ & $\begin{array}{l}93.3 \\
6.7\end{array}$ & $\begin{array}{c}24 \\
6\end{array}$ & $\begin{array}{l}80.0 \\
20.0\end{array}$ & $\begin{array}{l}4 \\
26\end{array}$ & $\begin{array}{l}13.3 \\
86.7\end{array}$ & $\begin{array}{c}46.89 \\
P=1.00\end{array}$ & $\begin{array}{l}28 \\
2\end{array}$ & $\begin{array}{c}93.3 \\
6.7\end{array}$ & $\begin{array}{l}18 \\
12\end{array}$ & $\begin{array}{l}60.0 \\
40.0\end{array}$ & $\begin{array}{c}3 \\
27\end{array}$ & $\begin{array}{l}10.0 \\
90.0\end{array} \mid$ & $\begin{array}{c}42.59 \\
P=1.00\end{array}$ & $\begin{array}{c}22 \\
8\end{array}$ & $\begin{array}{l}73.3 \\
26.7\end{array}$ & $\begin{array}{c}24 \\
6\end{array}$ & $\begin{array}{l}80.0 \\
20.0\end{array}$ & $\begin{array}{c}2 \\
28\end{array}$ & $\begin{array}{c}6.7 \\
93.3\end{array}$ & $\begin{array}{l}39.64 \\
P=0.00\end{array}$ \\
\hline $\begin{array}{l}\text { Ginger group } \\
\text { Yes } \\
\mathrm{N}_{0}\end{array}$ & $\begin{array}{l}18 \\
12 \\
\end{array}$ & $\begin{array}{l}60.0 \\
40.0 \\
\end{array}$ & $\begin{array}{r}7 \\
23 \\
\end{array}$ & $\begin{array}{l}23.3 \\
76.7 \\
\end{array}$ & $\begin{array}{c}4 \\
26 \\
\end{array}$ & $\begin{array}{l}13.3 \\
86.7 \\
\end{array}$ & $\begin{array}{c}16.59 \\
\mathrm{P}=0.00\end{array}$ & $\begin{array}{l}21 \\
9 \\
\end{array}$ & \begin{tabular}{|}
70.0 \\
30.0 \\
\end{tabular} & $\begin{array}{l}11 \\
19 \\
\end{array}$ & $\begin{array}{l}36.7 \\
63.3\end{array}$ & $\begin{array}{c}1 \\
29 \\
\end{array}$ & $\begin{array}{r}3.3 \\
96.7 \\
\end{array}$ & $\begin{array}{c}28.71 \\
P=0.00\end{array}$ & $\begin{array}{l}20 \\
10 \\
\end{array}$ & $\begin{array}{l}66.7 \\
33.3 \\
\end{array}$ & $\begin{array}{c}8 \\
22 \\
\end{array}$ & $\begin{array}{l}26.7 \\
73.3 \\
\end{array}$ & $\begin{array}{c}6 \\
24 \\
\end{array}$ & $\begin{array}{l}20.0 \\
80.0 \\
\end{array}$ & $\begin{array}{l}16.26 \\
P=0.00\end{array}$ \\
\hline $\begin{array}{l}\text { Significant } \\
\text { between } \\
\text { three groups }\end{array}$ & & & & 91.05 & $\mathrm{P}=0.0$ & & & & & $X^{2}=8$ & 83.07,P & $\mathrm{P}=0.00$ & & & & & & $62.43, P$ & $=0.00$ & & \\
\hline
\end{tabular}

$X^{2}$ : Chi-Square test

Significance at $P \leq 0.05$ 
Acupressure,Ginger, Chemotherapy GIT Side-Effects

Table (3): Chemotherapy Gastrointestinal Side -Effects of Children Experienced Vomiting in the Three Groups

\begin{tabular}{|c|c|c|c|c|c|c|c|c|c|c|c|c|c|c|c|c|c|c|c|c|c|}
\hline \multirow{3}{*}{$\begin{array}{l}\text { Experience of } \\
\text { vomiting }\end{array}$} & \multicolumn{6}{|c|}{$\begin{array}{c}1^{\text {st }} \text { session } \\
(\mathrm{n}=30)\end{array}$} & \multirow{3}{*}{$\begin{array}{l}\mathrm{Sig} \\
\mathrm{X}^{2}\end{array}$} & \multicolumn{6}{|c|}{$\begin{array}{c}2^{\text {nd }} \text { session } \\
(\mathrm{n}=30)\end{array}$} & \multirow{3}{*}{$\begin{array}{l}\text { Sig } \\
X^{2}\end{array}$} & \multicolumn{6}{|c|}{$\begin{array}{c}3^{\text {rd }} \text { session } \\
(\mathrm{n}=30)\end{array}$} & \multirow{3}{*}{$\begin{array}{l}\text { Sig } \\
\\
\mathrm{X}^{2}\end{array}$} \\
\hline & \multicolumn{2}{|c|}{ Day 1} & \multicolumn{2}{|c|}{ Day 2} & \multicolumn{2}{|c|}{ Day 3} & & \multicolumn{2}{|c|}{ Day 1} & \multicolumn{2}{|c|}{ day 2} & \multicolumn{2}{|c|}{ Day 3} & & \multicolumn{2}{|c|}{ Day 1} & \multicolumn{2}{|c|}{ Day 2} & \multicolumn{2}{|c|}{ Day 3} & \\
\hline & $\mathrm{N}$ & $\%$ & $\mathrm{~N}$ & $\%$ & $\mathrm{~N}$ & $\%$ & & $\mathrm{~N}$ & $\%$ & $\mathrm{~N}$ & $\%$ & $\mathrm{~N}$ & $\%$ & & $\mathrm{~N}$ & $\%$ & $\mathrm{~N}$ & $\%$ & $\mathrm{~N}$ & $\%$ & \\
\hline $\begin{array}{l}\text { Control } \\
\text { group } \\
\text { Yes } \\
\text { No }\end{array}$ & 30 & $\begin{array}{l}100.0 \\
0.0\end{array}$ & 30 & $\begin{array}{c}100.0 \\
0.0\end{array}$ & 30 & $\begin{array}{l}100.0 \\
0.0\end{array}$ & $\begin{array}{c}26.74 \\
\mathrm{P}=0.00\end{array}$ & 30 & $\begin{array}{l}100.0 \\
0.0\end{array}$ & $\begin{array}{l}30 \\
0\end{array}$ & $\begin{array}{c}100.0 \\
0.0\end{array}$ & $\begin{array}{c}30 \\
0\end{array}$ & $\begin{array}{l}100.0 \\
0.0\end{array}$ & $\begin{array}{c}26.74 \\
\mathrm{P}=0.00\end{array}$ & 30 & $\begin{array}{l}100.0 \\
0.0\end{array}$ & $\begin{array}{l}30 \\
0\end{array}$ & $\begin{array}{l}100.0 \\
0.0\end{array}$ & $\begin{array}{l}24 \\
6\end{array}$ & $\begin{array}{l}80.0 \\
20.0\end{array}$ & $\begin{array}{l}34,60 \\
P=0.00\end{array}$ \\
\hline $\begin{array}{l}\text { Acupressure } \\
\text { group } \\
\text { Yes } \\
\text { No }\end{array}$ & 22 & $\begin{array}{l}73.3 \\
26.7\end{array}$ & 27 & $\begin{array}{l}10.0 \\
90.0\end{array}$ & 29 & $\begin{array}{l}3.3 \\
96.7\end{array}$ & $\begin{array}{c}43.59 \\
\mathrm{P}=0.00\end{array}$ & 12 & $\begin{array}{l}60.0 \\
40.0\end{array}$ & $\begin{array}{l}3 \\
27\end{array}$ & $\begin{array}{l}10.0 \\
90.0\end{array}$ & $\begin{array}{l}2 \\
28\end{array}$ & $\begin{array}{l}6.7 \\
93.3\end{array}$ & $\begin{array}{c}28.15 \\
\mathrm{P}=0.00\end{array}$ & 16 & $\begin{array}{l}46.7 \\
53.3\end{array}$ & $\begin{array}{l}6 \\
24\end{array}$ & $\begin{array}{l}20.0 \\
80.0\end{array}$ & 30 & $\begin{array}{l}0.0 \\
100.0\end{array}$ & $\begin{array}{r}19.03 \\
P=0.00\end{array}$ \\
\hline $\begin{array}{l}\text { Ginger group } \\
\text { Yes } \\
\mathrm{N}_{0}\end{array}$ & 21 & $\begin{array}{l}30.0 \\
70.0\end{array}$ & 30 & $\begin{array}{c}0.0 \\
100.0\end{array}$ & 30 & $\begin{array}{l}0.0 \\
100.0\end{array}$ & $\begin{array}{c}20.0 \\
\mathrm{P}=0.00\end{array}$ & 20 & 33.3 & $\begin{array}{l}4 \\
26\end{array}$ & 13.3 & $\begin{array}{l}1 \\
29\end{array}$ & $\begin{array}{c}3.3 \\
96.7\end{array}$ & $\begin{array}{c}10.02 \\
\mathrm{P}=0.01\end{array}$ & 11 & 36.7 & 30 & $\begin{array}{l}0.0 \\
100.0\end{array}$ & 28 & $\begin{array}{l}6.7 \\
93.3\end{array}$ & $\begin{array}{l}18.52 \\
\mathrm{P}=0.00\end{array}$ \\
\hline $\begin{array}{l}\text { Significant } \\
\text { between } \\
\text { three groups }\end{array}$ & & & & 2.67 , & & & & & & & 31.7 & $P=0.01$ & & & & & & 71.09, & $=0.00$ & & \\
\hline
\end{tabular}

$X^{2}$ : Chi-Square test

Significance at $P \leq 0.05$ 
Acupressure,Ginger, Chemotherapy GIT Side-Effects

Table (4): Chemotherapy Gastrointestinal Side- Effects of Children Experienced Diarrhea in the Three Groups

\begin{tabular}{|c|c|c|c|c|c|c|c|c|c|c|c|c|c|c|c|c|c|c|c|c|c|}
\hline \multirow{3}{*}{$\begin{array}{l}\text { Experience of } \\
\text { diarrhea }\end{array}$} & \multicolumn{6}{|c|}{$\begin{array}{l}1^{\text {st }} \text { session } \\
(\mathrm{n}=30)\end{array}$} & \multirow{3}{*}{$\begin{array}{l}\text { Sig } \\
\mathrm{X}^{2}\end{array}$} & \multicolumn{6}{|c|}{$\begin{array}{c}2^{\text {nd }} \text { session } \\
(\mathrm{n}=30)\end{array}$} & \multirow{3}{*}{$\begin{array}{l}\text { Sig } \\
X^{2}\end{array}$} & \multicolumn{6}{|c|}{$\begin{array}{l}3^{\text {rd }} \text { session } \\
(\mathrm{n}=30)\end{array}$} & \multirow{3}{*}{$\begin{array}{l}\text { Sig } \\
\mathrm{X}^{2}\end{array}$} \\
\hline & \multicolumn{2}{|c|}{ Day 1} & \multicolumn{2}{|c|}{ Day 2} & \multicolumn{2}{|c|}{ Day 3} & & \multicolumn{2}{|c|}{ Day 1} & \multicolumn{2}{|c|}{ day 2} & \multicolumn{2}{|c|}{ Day 3} & & \multicolumn{2}{|c|}{ Day 1} & \multicolumn{2}{|c|}{ Day 2} & \multicolumn{2}{|c|}{ Day 3} & \\
\hline & $\mathrm{N}$ & $\%$ & $\mathrm{~N}$ & $\%$ & $\mathrm{~N}$ & $\%$ & & $\mathrm{~N}$ & $\%$ & $\mathrm{~N}$ & $\%$ & $\mathrm{~N}$ & $\%$ & & $\mathrm{~N}$ & $\%$ & $\mathrm{~N}$ & $\%$ & $\mathrm{~N}$ & $\%$ & \\
\hline $\begin{array}{l}\text { Control } \\
\text { group } \\
\text { Yes } \\
\text { No }\end{array}$ & $\begin{array}{c}5 \\
25\end{array}$ & $\begin{array}{l}16.7 \\
83.3\end{array}$ & $\begin{array}{c}0 \\
30\end{array}$ & $\begin{array}{l}0.0 \\
100.0\end{array}$ & $\begin{array}{l}0 \\
30\end{array}$ & $\begin{array}{l}0.0 \\
100.0\end{array}$ & $\begin{array}{c}6.21 \\
\mathrm{P}=0.05\end{array}$ & $\begin{array}{l}3 \\
27\end{array}$ & $\begin{array}{l}10.0 \\
90.0\end{array}$ & $\begin{array}{c}0 \\
30\end{array}$ & $\begin{array}{c}0.0 \\
100.0\end{array}$ & $\begin{array}{c}0 \\
30\end{array}$ & $\begin{array}{c}0.0 \\
100.0\end{array}$ & $\begin{array}{c}6.21 \\
P=0.05\end{array}$ & $\begin{array}{l}4 \\
26\end{array}$ & $\begin{array}{l}13.3 \\
86.7\end{array}$ & $\begin{array}{c}0 \\
30\end{array}$ & $\begin{array}{l}0.0 \\
100.0\end{array}$ & $\begin{array}{c}0 \\
30\end{array}$ & $\begin{array}{l}0.0 \\
100.0\end{array}$ & $\begin{array}{c}8.37 \\
\mathrm{P}=0.02\end{array}$ \\
\hline $\begin{array}{l}\text { Acupressure } \\
\text { group } \\
\text { Yes } \\
\mathrm{N}_{0}\end{array}$ & 27 & $\begin{array}{l}10.0 \\
90.0\end{array}$ & 30 & 0.0 & 30 & 100.0 & $\begin{array}{c}10.59 \\
P=0.01\end{array}$ & 30 & $\begin{array}{l}0.0 \\
100.0\end{array}$ & $\begin{array}{l}0 \\
30\end{array}$ & 100.0 & $\begin{array}{l}0 \\
30\end{array}$ & $\begin{array}{l}0.0 \\
100.0\end{array}$ & $\begin{array}{c}0.00 \\
P=1.00\end{array}$ & 30 & $\begin{array}{l}0.0 \\
100.0\end{array}$ & $\begin{array}{l}0 \\
30\end{array}$ & $\begin{array}{l}0.0 \\
100.0\end{array}$ & $\begin{array}{l}0 \\
30\end{array}$ & \begin{tabular}{l|}
0.0 \\
100.0 \\
\end{tabular} & $\begin{array}{c}0.00 \\
P=1.00\end{array}$ \\
\hline $\begin{array}{l}\text { Ginger group } \\
\text { Yes } \\
\mathrm{N}_{0}\end{array}$ & $\begin{array}{c}1 \\
29\end{array}$ & $\begin{array}{l}3.3 \\
96.7\end{array}$ & $\begin{array}{c}0 \\
30\end{array}$ & $\begin{array}{l}0.0 \\
100.0\end{array}$ & $\begin{array}{c}0 \\
30\end{array}$ & $\begin{array}{l}0.0 \\
100.0\end{array}$ & $\begin{array}{c}2.02 \\
\mathrm{P}=0.36\end{array}$ & $\begin{array}{c}0 \\
30\end{array}$ & $\begin{array}{c}0.0 \\
100.0\end{array}$ & $\begin{array}{c}0 \\
30\end{array}$ & $\begin{array}{c}0.0 \\
100.0\end{array}$ & $\begin{array}{c}0 \\
30\end{array}$ & $\begin{array}{l}0.0 \\
100.0\end{array}$ & $\begin{array}{l}0.00 \\
P=1.00\end{array}$ & $\begin{array}{l}0 \\
30\end{array}$ & $\begin{array}{l}0.0 \\
100.0\end{array}$ & $\begin{array}{c}0 \\
30\end{array}$ & $\begin{array}{l}0.0 \\
100.0\end{array}$ & $\begin{array}{c}0 \\
30\end{array}$ & $\begin{array}{l}0.0 \\
100.0\end{array}$ & $\begin{array}{c}0.00 \\
\mathrm{P}=1.00\end{array}$ \\
\hline $\begin{array}{l}\text { Significant } \\
\text { between } \\
\text { three groups }\end{array}$ & & & & 2.10, & $=0.2 J$ & & & & & & $6.07, \mathrm{P}=$ & $=0.05$ & & & & & & $0.12,1=$ & $=0.02$ & & \\
\hline
\end{tabular}

$X^{2}$ : Chi-Square test

Significance at $P \leq 0.05$ 
Acupressure,Ginger, Chemotherapy GIT Side-Effects

Table (4): Chemotherapy Gastrointestinal Side-Effects of Children Experienced Dehydration in the Three Groups

\begin{tabular}{|c|c|c|c|c|c|c|c|c|c|c|c|c|c|c|c|c|c|c|c|c|c|}
\hline \multirow{3}{*}{$\begin{array}{l}\text { Experience of } \\
\text { dehydration }\end{array}$} & \multicolumn{6}{|c|}{$\begin{array}{c}1^{\text {st }} \text { session } \\
(\mathrm{n}=30)\end{array}$} & \multirow{3}{*}{$\begin{array}{l}\text { Sig } \\
\mathrm{X}^{2}\end{array}$} & \multicolumn{6}{|c|}{$\begin{array}{c}2^{\text {nd }} \text { session } \\
(\mathrm{n}=30)\end{array}$} & \multirow{3}{*}{$\begin{array}{l}\text { Sig } \\
\mathrm{X}^{2}\end{array}$} & \multicolumn{6}{|c|}{$\begin{array}{c}3^{\text {rd }} \text { session } \\
(\mathrm{n}=30) \\
\end{array}$} & \multirow{3}{*}{$\begin{array}{l}\text { Sig } \\
X^{2}\end{array}$} \\
\hline & \multicolumn{2}{|c|}{ Day 1} & \multicolumn{2}{|c|}{ Day 2} & \multicolumn{2}{|c|}{ Day 3} & & \multicolumn{2}{|c|}{ Day 1} & \multicolumn{2}{|c|}{ day 2} & \multicolumn{2}{|c|}{ Day 3} & & \multicolumn{2}{|c|}{ Day 1} & \multicolumn{2}{|c|}{ Day 2} & \multicolumn{2}{|c|}{ Day 3} & \\
\hline & $\mathrm{N}$ & $\%$ & $\mathrm{~N}$ & $\%$ & $\mathrm{~N}$ & $\%$ & & $\mathrm{~N}$ & $\%$ & $\mathrm{~N}$ & $\%$ & $\mathrm{~N}$ & $\%$ & & $\mathrm{~N}$ & $\%$ & $\mathrm{~N}$ & $\%$ & $\mathrm{~N}$ & $\%$ & \\
\hline $\begin{array}{l}\text { Control } \\
\text { group } \\
\text { Yes } \\
\text { No }\end{array}$ & $\begin{array}{c}5 \\
25\end{array}$ & $\begin{array}{l}16.7 \\
83.3\end{array}$ & $\begin{array}{l}0 \\
30\end{array}$ & $\begin{array}{l}0.0 \\
100.0\end{array}$ & $\begin{array}{l}0 \\
30\end{array}$ & $\begin{array}{l}0.0 \\
100.0\end{array}$ & $\begin{array}{c}0.00 \\
\mathrm{P}=1.00\end{array}$ & $\begin{array}{l}0 \\
30\end{array}$ & $\begin{array}{c}0.0 \\
100.0\end{array}$ & $\begin{array}{l}0 \\
30\end{array}$ & $\begin{array}{c}0.0 \\
100.0\end{array}$ & $\begin{array}{l}0 \\
30\end{array}$ & $\begin{array}{l}0.0 \\
100.0\end{array}$ & $\begin{array}{c}0.00 \\
\mathrm{P}=1.00\end{array}$ & $\begin{array}{l}2 \\
28\end{array}$ & $\begin{array}{l}6.7 \\
93.3\end{array}$ & $\begin{array}{l}0 \\
30\end{array}$ & $\begin{array}{l}0.0 \\
100.0\end{array}$ & $\begin{array}{l}0 \\
30\end{array}$ & $\begin{array}{l}0.0 \\
100.0\end{array}$ & $\begin{array}{c}4.09 \\
P=0.13\end{array}$ \\
\hline $\begin{array}{l}\text { Acupressure } \\
\text { group } \\
\text { Yes } \\
\mathrm{N}_{0}\end{array}$ & $\begin{array}{l}3 \\
27\end{array}$ & $\begin{array}{l}10.0 \\
90.0\end{array}$ & $\begin{array}{l}0 \\
30\end{array}$ & $\begin{array}{l}0.0 \\
100.0\end{array}$ & $\begin{array}{l}0 \\
30\end{array}$ & $\begin{array}{l}0.0 \\
100.0\end{array}$ & $\begin{array}{c}6.21 \\
P=0.05\end{array}$ & 0 & $\begin{array}{l}0.0 \\
100.0\end{array}$ & $\begin{array}{l}0 \\
30\end{array}$ & $\begin{array}{l}0.0 \\
100.0\end{array}$ & $\begin{array}{l}0 \\
30\end{array}$ & $\begin{array}{c}0.0 \\
100 . \\
0\end{array}$ & $\begin{array}{c}0.00 \\
\mathrm{P}=1.00\end{array}$ & 30 & $\begin{array}{c}0.0 \\
100 . \\
0\end{array}$ & $\begin{array}{l}0 \\
30\end{array}$ & $\begin{array}{l}0.0 \\
100.0\end{array}$ & $\begin{array}{l}0 \\
30\end{array}$ & $\begin{array}{l}0.0 \\
100.0\end{array}$ & $\begin{array}{c}0.00 \\
P=1.00\end{array}$ \\
\hline $\begin{array}{l}\text { Ginger group } \\
\text { Yes } \\
\text { No }\end{array}$ & $\begin{array}{c}1 \\
29\end{array}$ & $\begin{array}{l}3.3 \\
96.7\end{array}$ & $\begin{array}{c}0 \\
30\end{array}$ & $\begin{array}{c}0.0 \\
100.0\end{array}$ & $\begin{array}{c}0 \\
30\end{array}$ & $\begin{array}{l}0.0 \\
100.0\end{array}$ & $\begin{array}{c}2.02 \\
\mathrm{P}=0.35\end{array}$ & $\begin{array}{l}0 \\
30\end{array}$ & $\begin{array}{c}0.0 \\
100.0\end{array}$ & $\begin{array}{c}0 \\
30\end{array}$ & $\begin{array}{c}0.0 \\
100.0\end{array}$ & $\begin{array}{l}0 \\
30\end{array}$ & $\begin{array}{c}0.0 \\
100.0\end{array}$ & $\begin{array}{c}0.00 \\
\mathrm{P}=1.00\end{array}$ & $\begin{array}{l}0 \\
30\end{array}$ & $\begin{array}{c}0.0 \\
100.0\end{array}$ & $\begin{array}{l}0 \\
30\end{array}$ & $\begin{array}{l}0.0 \\
100.0\end{array}$ & $\begin{array}{c}0 \\
30\end{array}$ & $\begin{array}{l}0.0 \\
100.0\end{array}$ & $\begin{array}{c}0.00 \\
P=1.00\end{array}$ \\
\hline $\begin{array}{l}\text { Significant } \\
\text { between } \\
\text { three groups }\end{array}$ & & & & $3.66,1$ & $=0.16$ & & & & & & $0.00, \mathrm{~F}$ & $=1.00$ & & & & & & 4.0J, & $=0.13$ & & \\
\hline
\end{tabular}

$X^{2}$ : Chi-Square test

Significance at $P \leq 0.05$ 


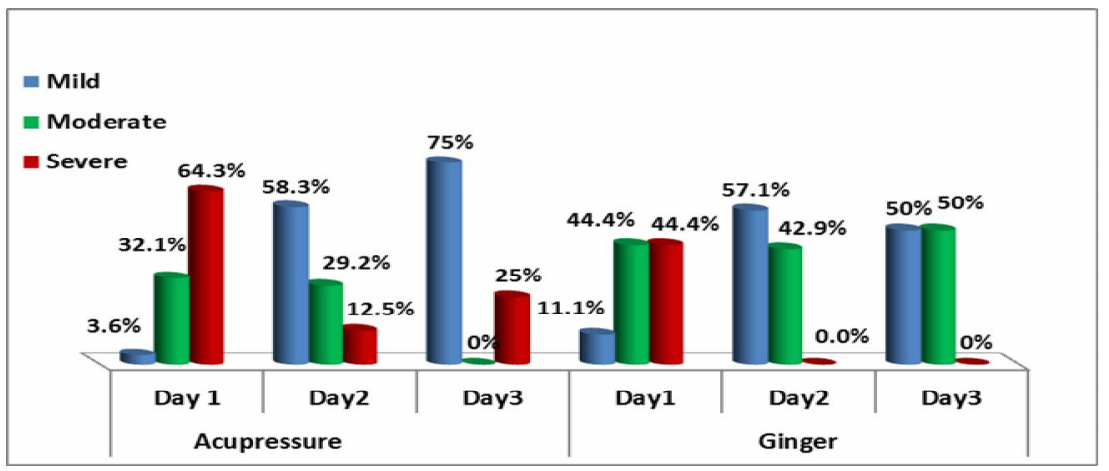

Figure (2): Severity of Nausea in the $1^{\text {st }}$ Session in Acupressure and Ginger Groups

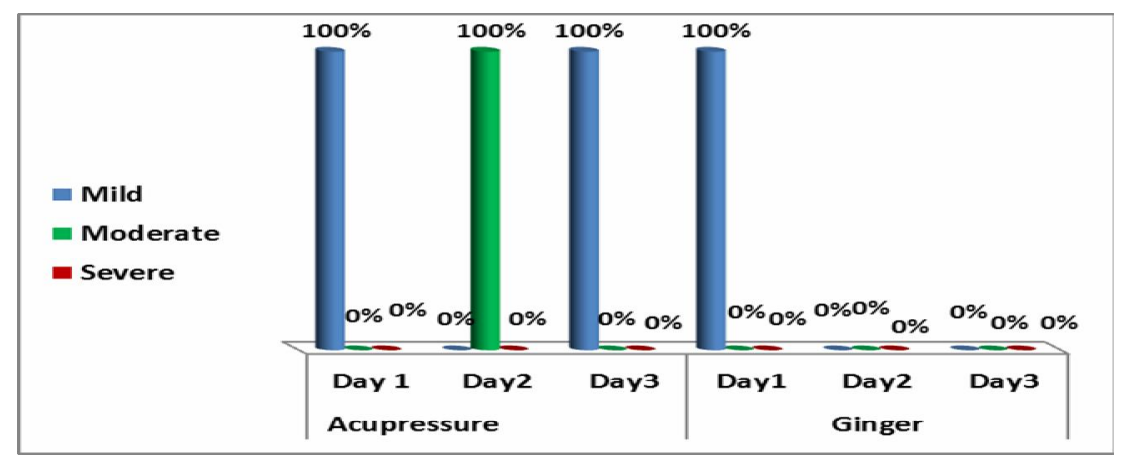

Figure (3): Severity of Vomiting in the 1st Session in Acupressure and Ginger Groups

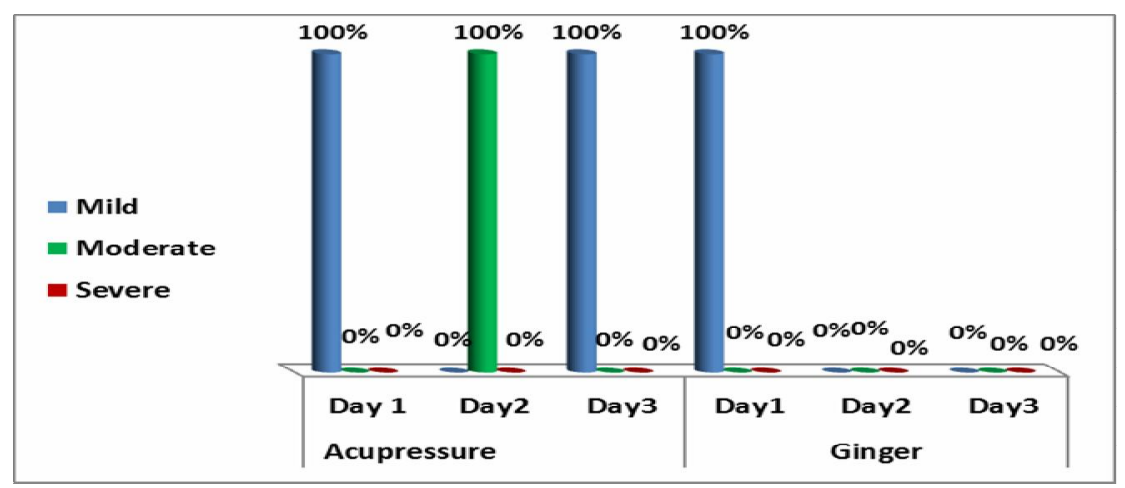

Figure (4): Severity of Nausea in the 2nd Session in Acupressure and Ginger Groups 


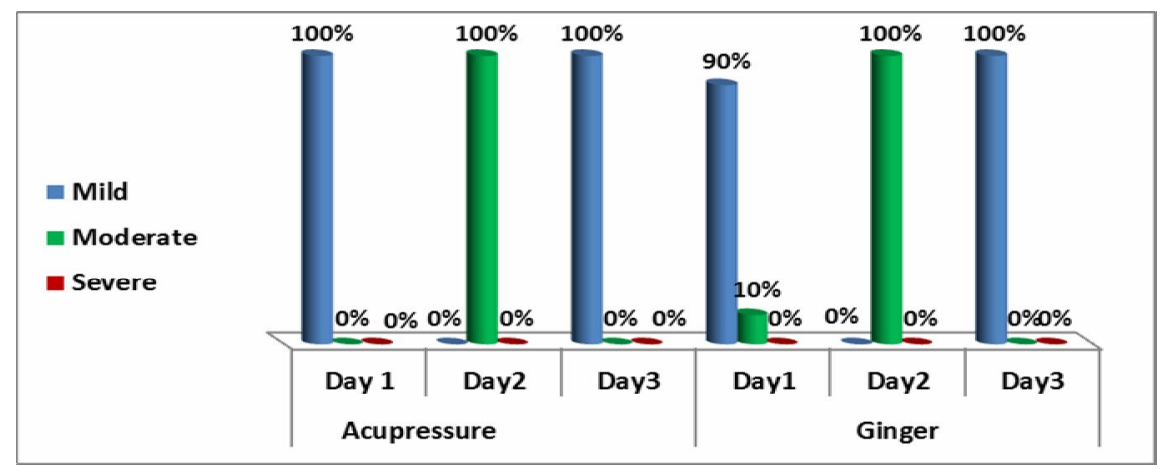

Figure (5): Severity of Nausea in the 2nd Session in Acupressure and Ginger Groups

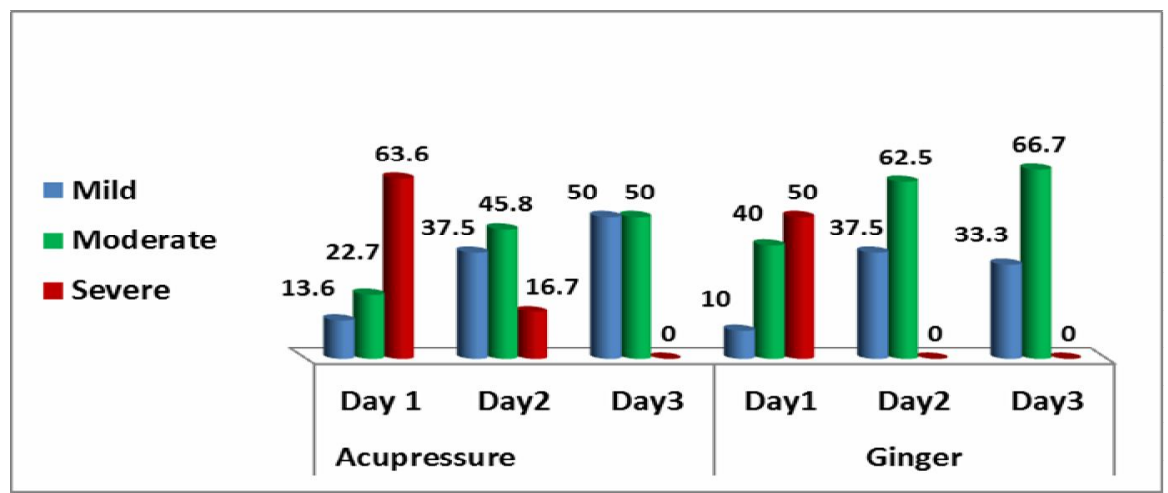

Figure (6): Severity of Nausea in the 3rd Session in Acupressure and Ginger Groups

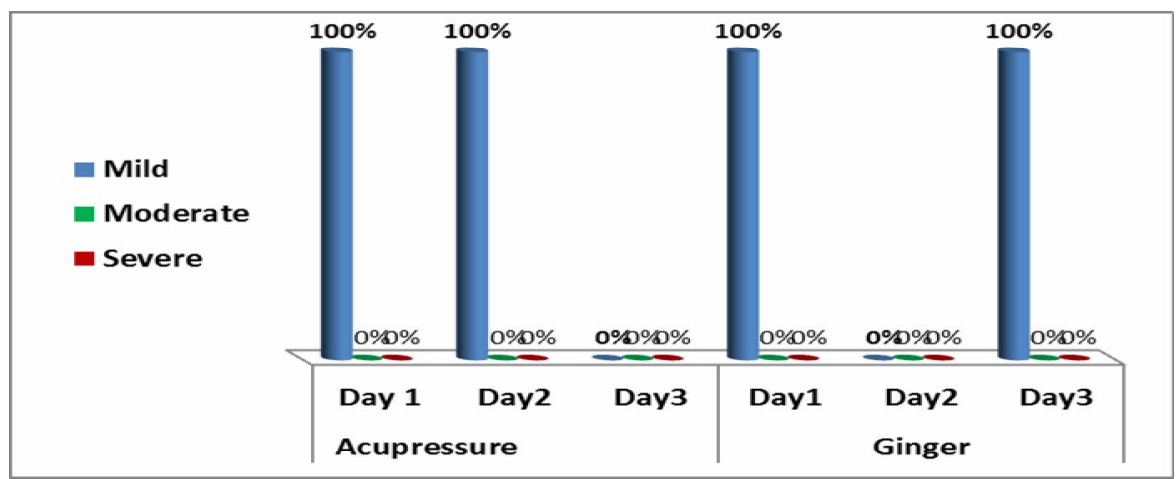

Figure (7): Severity of Vomiting in the 3rd Session in Acupressure and Ginger Group 


\section{References}

1. Hockenberg M \& Wilson D. Wong's Nursing Care of Infants and Children.10 ed. Canada; St. Louis\& Mosby's co. 2015.pp: 1398-1402.

2. Grigoropoulos F, Petter R, Van T, Veer B, \&Scott A. Leukemia Update. Part 1: Diagnosis and management. BMJ . 2013; 346(1):116-24.

3. Metayer C, Milne E, Clavel J. The Childhood Leukemia International Consortium. Cancer Epidemiol. 2013; 37(3): 336-47.

4. American Cancer Society. Cancer facts and figures. (2018). Available at: https://www.cancer.org/content/dam/cancer -org/research/cancer-facts-andstatistics/annual-cancer-facts-andfigures/2018/cancer-facts-and-figures2018.pdf.

5. American Cancer Society. Cancer facts and figures. (2019a) Available at: https://www.cancer.org/research/cancerfacts-statistics/all-c.

6. American Cancer Society. Chemotherapy for childhood leukemia. (2019b). Available at:

https://www.cancer.org/cancer/leukemiain-children/treating/chemotherapy.html.

7. Tageja $\mathrm{N} \&$ Groninger H. ChemotherapyInduced Nausea and Vomiting: An overview and Comparison of Three Consensus Guidelines. Postgraduate Medical Journal 2016; 92(1083): 34-40.

8. Maroun J, Anthony B \& Burkes D. Prevention and Management of Chemotherapy-Induced Diarrhea in Patients with Colorectal Cancer: A consensus statement by the canadian working group on chemotherapy-induced diarrhea. Current Oncology Journal 2017; 14(1): 13-20.

9. Shin H., Kim I, Shin S, Juon S. Effect of Acupressure on Nausea and Vomiting during Chemotherapy Cycle for korean Postoperative Stomach Cancer Patients Cancer Nursing. Cancer Nurs. 2004; 27(4): 267-74.

10. Dent E, Dewhurst G, Mills S \&Willoughby M. Continuous PC6 Wristband Acupressure for Relief of Nausea and Vomiting Associated with Acute Myocardial Infarction: A partially Randomized, Placebo-Controlled Trial. Complement Ther Med. 2003; 11(2): 72-7.
11. Ruggiero A, Rizzo D, Catalano M, Coccia $\mathrm{P}$, Triarico S \&Giorgio A. Acute Chemotherapy-Induced Nausea and Vomiting in Children with Cancer: Still Waiting for a Common Consensus on Treatment. Journal of International Medical Research 2018; 46(6): 2149-56.

12. Khalili Z, Khatiban M, Faradmal J, Abbasi M, Zeraati F\&Khazaei A. Effect of Cardamom Aromas on the ChemotherapyInduced Nausea and Vomiting in Cancer Patients. Avicenna J Nursing Midwifery Care 2014; 22(3): 64-73.

13. 13. Navari M. Management of Chemotherapy-Induced Nausea and Vomiting in Pediatric Patients. Paediatr Drugs 2017; 19(3):213-22.

14. Jordan K, Gralla R, Jahn F\& Molassiotis A. International Antiemetic Guidelines on Chemotherapy Induced Nausea and Vomiting (CINV): Content and Implementation in Daily Routine Practice. Eur J Pharmacol. 2014; 5(722): 197-202.

15. Viljoen E, Visser J, Koen N \& Musekiwa A. A systematic Review and Meta-analysis of the Effect and Safety of Ginger in the Treatment of Pregnancy-Associated Nausea and Vomiting. Nutr J. 2014; 13(2): 20-5.

16. Ernst E \& Pittler H. Efficacy of Ginger for Nausea and Vomiting: A systematic Review of the Randomized Clinical Trials. Br J Anaesth. 2000; 84(3): 367-71.

17. World Health Organization. Integrated Management of Childhood Illness (Module 4): Diarrhea. WHO. 2014. Available at: https://www.ecu.edu/csdhs/ghp/upload/101415 WHO...

18. Fairbank J\& Davies J. Quadruple Visual Analog Scale, Theoswestry Low Back Pain Disability questionnaire. Physiother J. 1980; 66(18): 271-73.

19. Baxter A. Visual Analog Scale for Nausea and Vomiting. Pediatrics Journal 2011; 127(6): 1542-9.

20. Loyd V. Allen Jr. Ph.D. Secundum Artem VOLUME 4 NUMBER 2 Current \& Practical Compounding Information for the Pharmacist.

21. Pillai AK, Sharma KK, Gupta YK, Bakhshi S. Anti-emetic Effect of Ginger Powder versus Placebo as an add-on Therapy in Children and Young Adults Receiving High Emetogenic Chemotherapy. Pediatric Blood Cancer 2011; 56(2):234-8. 
22. Larsen A. Acupuncture point: Pericardium 6. 2018. Retrieved from: https://www.miridiatech.com/news/2016/05 /acupuncture-point-pericardium-6/.

23. Baek A. Factors Influencing Quality of Life during Chemotherapy for Colorectal Cancer Patients in South Korea. Journal of Korean Academy Nursing 2015; 45(4): 604-12.

24. 24. Khakpour M, Dabbaghi B \&Javid A. Efficacy of Acupressure on Nausea and Vomiting in Children Undergoing Chemotherapy: A Systematic Review. International Journal of Pediatrics 2019; 7(6): 9601-10.

25. Yousef Y, Zaki N \&Abd-Alasis A. Effect of Therapeutic Massage on Nausea and Vomiting among Children with Leukemia Following Chemotherapy. Journal of Nursing and Health Science. 2018; 7(6):1321.

26. Lete I\& Allué J .The Effectiveness of Ginger in the Prevention of Nausea and Vomiting During Pregnancy and Chemotherapy. Integr Med Insights 2016; 11(1): 11-17.

27. Mustian K, Devine K, Ryan L, PhD, MPH, Janelsins M, PhD, Sprod L, Peppone L, Candelario G, Mohile S \&Morrow G. Treatment of Nausea and Vomiting During Chemotherapy. US Oncol Hematol J. 2011; 7(2): 91-97.

28. Jellin M, Gregor J, Batz F \& Hitchens K. Pharmacist's Letter/ Prescriber's Letter Natural Medicines Comprehensive Database. $4^{\text {th }}$ ed. Philadelphia, PA: Lippincott Williams\&Willkins.2002; pp: 584-86.

29. Sontakke S, Thawani V \&Naik M . Ginger as An antiemetic in Nausea and Vomiting Induced by Chemotherapy: A randomized, Cross-over Double Blind Study. Indian Journal of Pharmacology 2003; 35(1):3236.

30. Saberi F, Sadat Z, Kalahroudi M \& Taebi M .Acupressure and Ginger to Relieve Nausea and Vomiting in Pregnancy: A randomized Study. Iran Red Crescent Med J. 2013; 15(9): 854-61.

31. 31. Alparslan G, OzkarmanA, Eskiehişr M, Eskin N, Yilmaz S, Akay M\& Acikgoz A. .Effect of Ginger on ChemotherapyInduced Nausea and Vomiting in Cancer Patients. Journal of the Australian Traditional Medicine Society 2012; 18(1): 18.
32. Zick M, Djuric $\mathrm{Z}$ \&Ruffin $\mathrm{T}$ Pharmacokinetics of [6]-Gingerol, [8]Gingerol, [10]-Gingerol, [6]-Shogaol and Conjugate Metabolites in Healthy Human Subjects. Cancer Epidemiol Biomarkers Prev. 2008; 17(8):1930-6.

33. Aly S, Al-Ghamdi A, Abd El Megeed M \& Al Sayegh A. Effect of Ginger Capsules Intake on Treating Morning Sickness in Early Pregnancy. Al-Azhar Assiut Medical Journal 2013; 11(1): 71-82.

34. Arslan M \& Ozdemir L. Oral Intake of Ginger for Chemotherapy-Induced Nausea and Vomiting among Women with Breast Cancer.Clinical Journal of Oncology Nursing 2015; 19(5): 92-7.

35. Arfeen Z, Owen $\mathrm{H}$, Plummer L, Isley $\mathrm{H}$, Adams S\& Doecke J. A double-Blind Randomized Controlled Trial of Ginger for the Prevention of Postoperative Nausea and Vomiting. Anaesth Intensive Care 1995; 23(4):449-52.

36. Arbuckle R, Huber S \&Zacker C. The consequences of Diarrhea Occurring During Chemotherapy for Colorectal Cancer. Oncologist 2000; 5(3): 250-9.

37. Khalili H, Dabaghzadeh F, DashtiKhavidaki S, Abbasian L \&Moeinifard A. Ginger for prevention of antiretroviralinduced nausea and vomiting: A randomized clinical trial. Expert Opin Drug Saf. 2014;13(7): 859-66.

38. World Health Organization. WHO monographs on Selected Medicinal Plants. 1999; pp: 277-85. Available at: http://apps.who.int/medicinedocs/en/d/Js22 00e/.

39. Zhoup F, Zhang L \& Xiong Z. The Effect of Acupuncture on ChemotherapyAssociated Gastrointestinal Symptoms in Gastric Cancer. Curr.Oncol. 2017; 24(1): $1-5$.

40. Mohammed H, Attia A, Hussein H \&Khaled W. Effect of Acupressure on Frequency and Severity of Nausea and Vomiting among Leukemic Children undergoing Chemotherapy .Medical Journal of Cairo University. 2018; 86 (3): 1465-73.

41. Melzack R. Pain Mechanisms: A new Theory. Journal of Science 1996; 150(1): 971-79.

42. Miao J, Liu X,Wu C, Kong H, Xie W\& Liu K. Effects of Acupressure on Chemotherapy-Induced Nausea and Vomiting; A systematic Review with Metaanalyses and Trial Sequential 
Analysis of Randomized Controlled Trials. International Journal of Nursing Studies 2017; 70(4): 27-37.

43. Kaur R \&Madaan D. An experimental Study to Assess Effectiveness of Acupressure on relief of chemotherapy induced nausea and vomiting among cancer patients in Selected Hospital, Punjab. International. J. Pharm. Sci. Rev. Res. 2015; 34(1): 243-46.

44. Abusaad F \& Ali W. Effect of Point 6 Acupressure on Chemotherapy Associated Nausea and Vomiting among Adolescent with Cancer. Journal of Nursing Education and Practice 2016; 6(4): 122-9.

45. Gao L, Jia C \& Huang H. Paediatric Massage for Treatment of Acute Diarrhea in Children: A meta-analysis. Complement Altern Med. 2018;18(1): 257.

46. Malagoli C, Malavolti M, Costanzini S, Fabbi S, Teggi S, Palazzi G, Arcolin, E \& Vinceti1 M. Increased Incidence of Childhood Leukemia in Urban Areas: A population-Based Case-Control Study. Epidemiol Prev. 2015; 39(4): 102-107.
47. Hockenbery M \& Wilson D. Wong's Nursing Care of Infants and Children .10th ed .St. Louis: Mosby's Co .2015; pp: 1398402.

48. Baraz S, Miladinia M, Malehi S, Alehi S \& Baeis G.. Effect of the Slow-Stroke Back Massage on Symptoms Cluster (Pain, Fatigue and Sleep disorders) in Patients with Acute Leukemia. Avicenna Journal of Phytomedicine 2015; 5 (24): 21.

49. Helmy I \& Hanafy H. Madkour's Essential of Pediatrics. $15^{\text {th }}$ ed. Alexandria: Ayad Press. 2016; pp: 215.

50. Esmail N, Darwish A, El-Sayed M, ElShanshory M \& El-Saadany H. Effect of Progressive Muscle Relaxation Technique versus Acupressure on Chemotherapy. International Journal of Current Research 2014; 6(7):7674-82. 